\title{
Workwear Fabric Suitability to Molten Metal Industry
}

\author{
Tuğçem Bitgen ${ }^{1}$, Bengi Kutlu² \\ ${ }^{1}$ Dokuz Eylul University, The Graduate School of Natural and Applied Sciences, Textile Engineering Department, Izmir-Turkey \\ ${ }^{2}$ Dokuz Eylul University, Faculty of Engineering, Textile Engineering Department, Izmir-Turkey
}

Corresponding Author: Bengi Kutlu, bengi.kutlu@deu.edu.tr

\begin{abstract}
In the scope of the foundry processes, there are vital risks when melting of metals at high temperatures, carrying this molten metal to molds and pouring it to molds. In this study, wide range of workwear materials which are used in foundries in Turkey were collected and their protection properties were investigated to observe their performances. Determining suitable material to molten metal processing was aimed. These workwear materials were produced from FR-cotton, cotton denim, modacrylic-viscose-FR cotton, meta-aramid, aluminized aramid, FR viscose-wool-polyamide and leather. Their performances were very different. Except from meta-aramid and both of the FR cotton fabrics, other fabrics failed flame spread. Contrary to flame spread, leather, aluminized aramid, FR viscose-wool-polyamide and cotton denim materials showed the highest values in molten metal splash test. Besides, leather had no air permeability but has some water vapor permeability and aluminized aramid has poor air and water permeabilities.
\end{abstract}

\section{ARTICLE HISTORY}

Received: 18.05 .2020

Accepted: 24.11.2020

\section{KEYWORDS}

Molten metal, workwear, protective clothing, molten aluminium, foundry

\section{INTRODUCTION}

Metal foundry industry in Turkey is one of the most important sectors taking 3rd place in Europe and 11th place in the world having nearly 34,000 employees of this industry. Aluminium die casting is rising in area Turkey, total production $20 \%$ increased from 2017 to 2018 . This is the reason of our decision to investigate aluminium protection properties of varios fabrics. Foundry process involves three main steps, heating metal until it becomes molten; pouring molten metal into a mold; and allowing the metal to cool and solidify in the shape of the mold. Correct casting temperatures are important for quality of cast product. Melting temperatures of metals are very high, i.e. $660^{\circ} \mathrm{C}$ for Aluminium, $1536^{\circ} \mathrm{C}$ for iron, etc. These processes endanger the life of workers; however, proper workwear can protect them. Wide range of fabrics are used in foundry workwear from cotton to special fibers like modacrylic, aramid, even leather and each of them has different performances and prices. In general, there are three types of molten metal exposures in industry: poured molten metal, welding droplets and molten metal splashes due to an electric arc. In foundry sector, poured molten metal is the main exposure for employees. In addition, foundries are very hot environments and this causes uncomfortable feelings causing loosing attention in shortterm exposure and heat stress hazards in longterm exposure. In protective product selection, temperature, density, size of droplets and the reactivity (sticking) of droplets are determining factors [1,2].

There are few works about molten metal protective textile materials, most of them rather old. Barker and Yener, worked on molten iron protection. They found iron resistance was correlated with fabric thickness, weight, air permeability and flammability properties [3]. Benisek, Edmondson and Philips aimed at measurement of protection properties of especially zirpro FR (flame retardant) wool and other protective clothing against convective and radiant heat and aluminum splashes. They developed the molten aluminum protection test method similar to recent one. They concluded that increased fabric weight and density, low thermal conductivity and smooth fabric surface were important for molten aluminium protection [4]. Benisek and Edmondson in 1981, evaluated the effects of different conductive heat sources as molten metals (cast iron, steel, copper, aluminium, zinc, lead and tin) on various FR fabrics. They indicated inherent flame

To cite this article: Bitgen T, Kutlu B. 2020. Workwear Fabric Suitability to Molten Metal Industry. Tekstil ve Konfeksiyon, 30(4), 289-295. 
retardant property (i.e. glass, asbestos and aramid fibers) is not sufficient for molten metal protection. Zirpro wool was find to be a good example of molten metal protection, untreated cotton showed slightly lower protection while FR treated cotton fibers worser than the others against aluminium and zinc [5]. Proctor and Thompson in 1992 focused on finished wool fibers and effects of the finish chemicals to molten metal adhesion. They found that chrome dyeing and zipro finish on wool increase adhesion of molten aluminium and zinc. This result of chrome dyeing is similar to the results from Benisek and Edmondson in 1984 [6, 7]. Coughlan worked with different fabrics against molten aluminium. It is found that damage to skin simulant was not dependent on flame retardancy but dependent on surface properties of fabrics at high temperatures and duration of molten metal-fabric contact (sticking). FR treatments on cotton causes sticking and softening of synthetic inherently flame retardant fibers occurs and causes trapping of metals are the other conclusions [8]. Magnússon et al., investigated molten aluminium protection properties of FR cotton, FRviscose/wool/cotton, viscoseFR/PVA/modacrylic, viscose FR/wool fabrics. They concluded that to obtain D3 level protection of ISO11612, underwear usage was essential. Additionally, they examined the behavior of molten aluminium when small and big folds occur in the fabric. If there was big fold, molten aluminiun may stop and cause damage in skin simulant [9]. Mäkinen et al. studied fabric layer combinations instead of single fabrics. They found that use of FR underwear is useful to increase the level of molten iron protection [10]. Lee highlighted the number of PPE advancements in Australia. Paper explained the preferred not only clothing but all components of personal protective equipment (PPE) [11].
Surveying literature, it is seen that molten metal protection properties of various fabrics were investigated in detail [311]. Although performances of certain types of fabrics are known, a workwear's overall performance cannot be concluded without mechanical performances and comfort properties convenient to work conditions. In addition, there are very wide range of workwear fabrics available and in use for foundry workers in Turkey. However, due to very high temperatures, carefully selected specific materials should be used regarding protection and the other performances. That was our motivation and in this research, we investigated primarily molten aluminium and flame protection properties of various fabrics and one leather sample, together with physical-mechanical and permeability features. Leather cannot be found in literature but it is in common use for molten metal processing especially as gloves and aprons. The aim of the research was to determine properties of fabrics and leather used in workwear clothing in Turkey and to assess the better material showing suitable performance.

\section{MATERIAL AND METHOD}

\subsection{Material}

Seven types of fabrics that are mostly used in workwear of Turkey's foundry industry and one type of leather were provided. Firstly, fabric structures, area weight (TS 251), thickness (TS $7128 \mathrm{EN}$ ISO $5084-5 \mathrm{~g} / \mathrm{cm}^{2}$ pressure), warp and weft yarn numbers, fabric settings and tensile strength (TS EN ISO 13934-1 for fabrics and TS EN ISO 3376 for leather) properties were determined. The results are given in Table 1.

Table 1. Physical properties of fabrics and leather

\begin{tabular}{|c|c|c|c|c|c|c|c|c|c|}
\hline Code & Samples & $\begin{array}{l}\text { Weave } \\
\text { Type }\end{array}$ & $\begin{array}{r}\text { Area } \\
\text { weight } \\
\left(\mathrm{g} / \mathrm{m}^{2}\right)\end{array}$ & $\begin{array}{r}\text { Fabric } \\
\text { Thickness } \\
(\mathbf{m m})\end{array}$ & $\begin{array}{l}\text { Weft count } \\
(\text { thread/cm) }\end{array}$ & $\begin{array}{r}\text { Warp } \\
\text { count } \\
\text { (thread/cm) }\end{array}$ & $\begin{array}{r}\text { Weft } \\
\text { yarn } \\
\text { number }\end{array}$ & $\begin{array}{r}\text { Warp } \\
\text { yarn } \\
\text { number }\end{array}$ & $\begin{array}{r}\text { Tensile } \\
\text { Strength }(\mathbf{N})\end{array}$ \\
\hline 101 & Meta-aramid & $\begin{array}{l}\text { Plain } \\
\text { weave }\end{array}$ & 248.61 & 0.642 & 30 & 19 & $\mathrm{Nm} 17$ & $\mathrm{Nm} 12$ & 1565.8 \\
\hline 102 & $\begin{array}{l}\text { Modacrylic- } \\
\text { Viscose-FR } \\
\text { cotton }\end{array}$ & twill $(2 / 2)$ & 249.23 & 0.474 & 33 & 30 & $\mathrm{Nm} 22$ & $\mathrm{Nm} 30$ & 603.7 \\
\hline 103 & $\begin{array}{l}\text { Cotton 1- FR1 } \\
\text { (Apyrol CEP- } \\
\text { CHT) }\end{array}$ & twill $(1 / 3)$ & 565.21 & 1.110 & 17 & 30 & $\mathrm{Nm} 14$ & $\mathrm{Nm} 12$ & 1026.5 \\
\hline 104 & Leather & - & 735.35 & 1.042 & - & - & - & - & 308.5 \\
\hline 105 & $\begin{array}{l}\text { Cotton 2- FR2 } \\
\text { (Proban- } \\
\text { Solvay) }\end{array}$ & twill $(1 / 5)$ & 331.06 & 0.708 & 30 & 41 & Nm 14 & $\mathrm{Nm} 22$ & 1194.5 \\
\hline 106 & $\begin{array}{l}\text { Aluminized } \\
\text { aramid }\end{array}$ & - & 273.52 & 0.736 & - & - & - & - & 884.0 \\
\hline 107 & $\begin{array}{l}\text { Cotton } \\
\text { Denim }\end{array}$ & twill $(2 / 2)$ & 431.42 & 0.780 & 24 & 32 & Nm 17 & $\mathrm{Nm} 12$ & 1387.4 \\
\hline 108 & $\begin{array}{l}\text { FRViscose- } \\
\text { Wool- } \\
\text { Polyamide }\end{array}$ & $\begin{array}{l}\text { Plain } \\
\text { weave }\end{array}$ & 420.68 & 0.770 & 30 & 30 & Nm 17 & Nm 17 & 592.4 \\
\hline
\end{tabular}




\subsection{Method}

Flame retardancy, molten metal protection, $\mathrm{pH}$ values, fat content of the leather, abrasion strength, resistance to water penetration, air and water vapor permeability features of the materials were examined.

ISO 15025 standard - procedure A was used for limited flame spread test. $\mathrm{pH}$ values that are important when materials contacts to skin were measured according to TS 477 EN 1413 for fabrics and TS EN ISO 4045 for leather. Fat content of the leather was found according to TS EN ISO 4048. In foundries, wearing out of clothing by mechanical effects are occurred, therefore, TS EN ISO 12947-1 was used to obtain abrasion resistance. 30000 cycles were applied to samples and after every 5000 cycles weight losses were calculated. Additionally, resistance to water penetration (TS 257 EN 20811), air (TS 391 EN ISO 9237) and water vapor permeability (BS 3424-24) tests were applied to observe permeability properties.

Molten metal protection was measured according to TS EN ISO 9185 standard with home-made device (Figure 1(a)). Aluminium (99.5\%) was used as metal. In this test method, certain amount of molten metal starting from 50grams is poured at a certain speed onto fabrics that are placed on $60^{\circ}$ inclined apparatus. Under fabric sample, a specific PVC film as skin simulant is used. At the end, 30s after completion of pouring, damage to skin simulant (not to fabric) is examined. The damage means $5 \mathrm{~mm}$ in width or bigger stain on skin simulator as seen in Figure 1(b). If there is no damage, test is repeated with new specimen using a quantity $50 \mathrm{~g}$ greater molten metal than the amount of previous test. If there is damage, test is repeated with new specimen using a quantity $10 \mathrm{~g}$ less than the amount of previous test. The result is the highest mass of metal poured that does not caused damage. So fabrics are ranked by the quantity of molten aluminium that they can protect skin in heat and flame protective workwear standard, ISO 11612. Molten alumnium protective fabrics or assemblies should meet the criteria at least level D1 (100g-199g) as protection from minimum $100 \mathrm{~g}$ of molten aluminium. (D2: $200 \mathrm{~g}$ $349 \mathrm{~g}$; D3: equal or higher than $350 \mathrm{~g}$ ) Aluminium pouring temperature is $780^{\circ} \mathrm{C}$ [2].

\section{RESULTS AND DISCUSSION}

\subsection{Tensile and Abrasion Strength of Samples}

Workwear fabrics must show protective properties against hazards in the workplaces, however, without durability of fabrics, protective excellence loose importance. In order to determine better material, breaking strength and elongation values of fabric samples were measured and shown in Table 2.

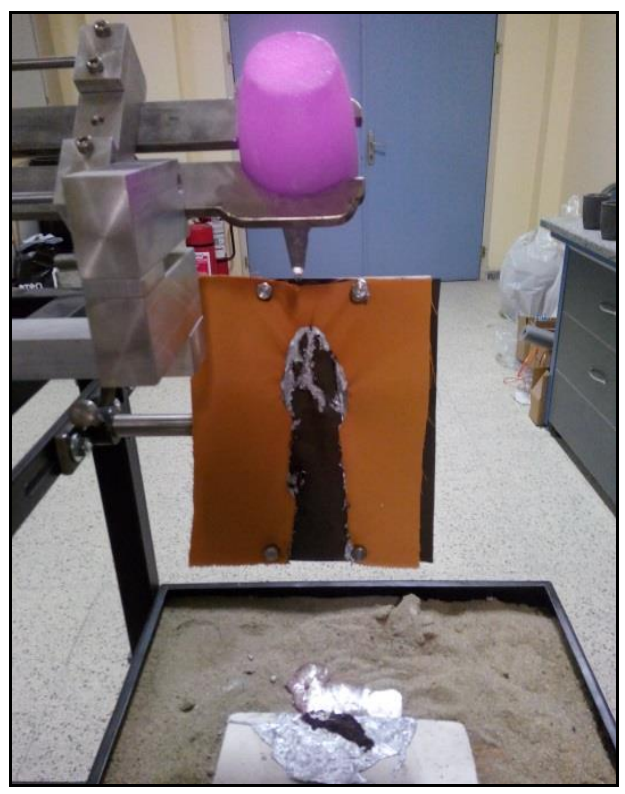

(a)

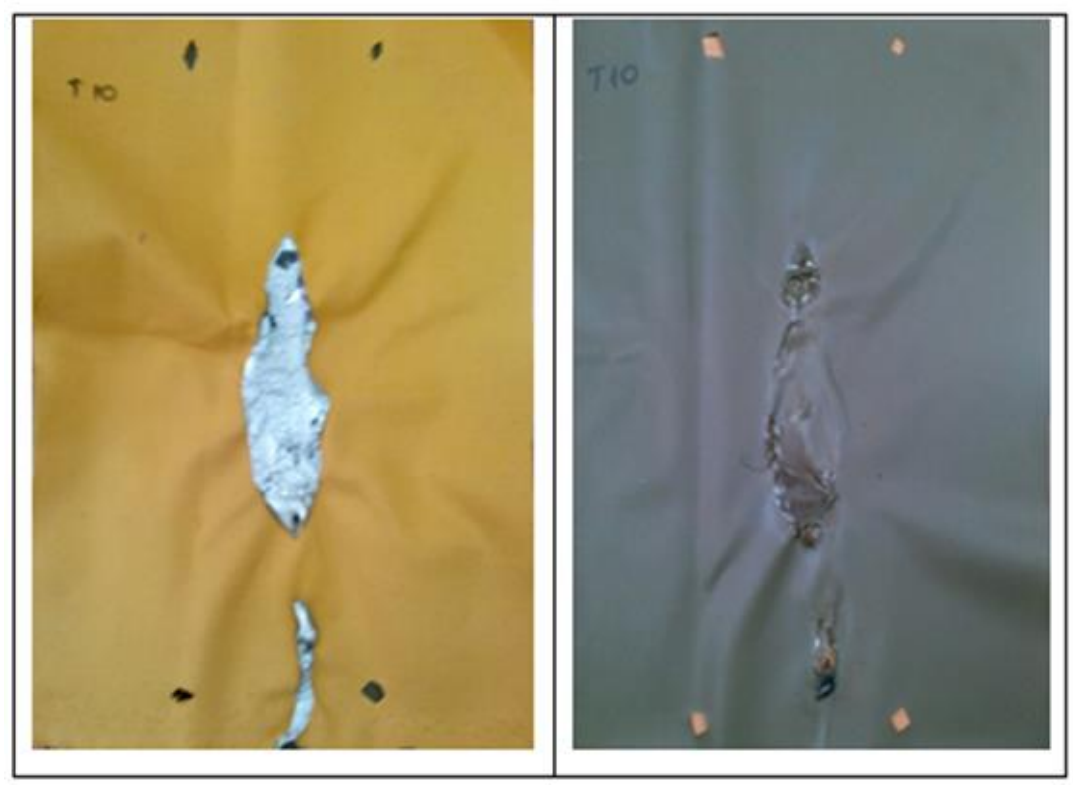

(b)

Figure 1. (a) Molten metal protection measurement device, (b) Damaged fabric and skin simulator with damage bigger than $5 \mathrm{~mm}$ in width (101-aramid fabric with $10 \mathrm{~g}$ of molten aluminium) 
Table 2. Tensile strength and elongation at break values of the samples

\begin{tabular}{|c|c|c|c|c|c|c|}
\hline $\begin{array}{l}\text { Fabric } \\
\text { Code }\end{array}$ & $\begin{array}{l}\text { Tensile Strength- } \\
\text { Weft direction } \\
\text { (N) }\end{array}$ & $\begin{array}{c}\text { Tensile } \\
\text { Strength-Warp } \\
\text { direction }(\mathbf{N})\end{array}$ & $\begin{array}{c}\text { Average Tensile } \\
\text { Strength }(\mathbf{N})\end{array}$ & Weft-elongation & Warp-elongation & $\begin{array}{c}\text { Average } \\
\text { Elongation }\end{array}$ \\
\hline 101 & 1602,5 & 1529,0 & 1565,8 & $\% 45,7$ & $\% 24,3$ & $\% 35,0$ \\
\hline 102 & 619,5 & 587,8 & 603,7 & $\% 19,4$ & $\% 26,9$ & $\% 23,2$ \\
\hline 103 & 889,2 & 1163,8 & 1026,5 & $\% 8,1$ & $\% 19,7$ & $\% 13,9$ \\
\hline 104 & - & - & 308,5 & - & - & $\% 49,1$ \\
\hline 105 & 1713,0 & 676,0 & 1194,5 & $\% 12,3$ & $\% 13,9$ & $\% 13,1$ \\
\hline 107 & 909,7 & 1865,1 & 1387,4 & $\% 13,0$ & $\% 27,2$ & $\% 17,2$ \\
\hline \multirow[t]{2}{*}{108} & 658,2 & 526,6 & 592,4 & $\% 21,4$ & $\% 30,5$ & $\% 28,9$ \\
\hline & Course direction & Wale direction & & Course direction & Wale direction & \\
\hline 106 & 844.8 & 923.9 & 884,0 & $\% 78,2$ & $\% 19,0$ & $\% 48,6$ \\
\hline
\end{tabular}

When look through the table, there are remarkable differences in the values. The reasons seem to be the types of weave and the fibers. Because meta-aramid fiber strength is inherently high. Cotton fabrics whose weave types were twill showed high strength values. Additionally, fiber strengths of cotton, wool, modacrylic and polyamide fibers are $0.45 \mathrm{~N} /$ tex, $0.11 \mathrm{~N} /$ tex, $0.27 \mathrm{~N} /$ tex and $0.29 \mathrm{~N} /$ tex, respectively. Course direction elongation of aluminized aramid was extremely high. This coated product was in warp knitted structure and the elongation extend can be seen in Figure 2. Three twill cotton fabrics have the lowest degrees of elongation because cotton fibers have lower elongation at break values than the other fibers [12-15].

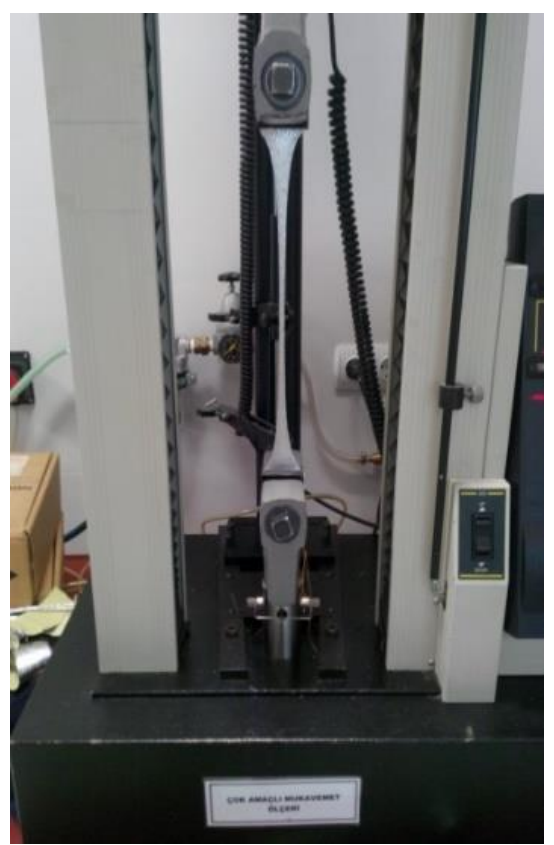

Figure 2. Elongation of aluminized aramid fabric

The same protective workwear piece may show different properties in different factories depending on product of the foundry, processing units, production conditions, etc. Abrasion resistance of fabrics is affected by fiber type, yarn properties, fabric structures and finishing treatmens [13]. The results are seen in Figure 3.

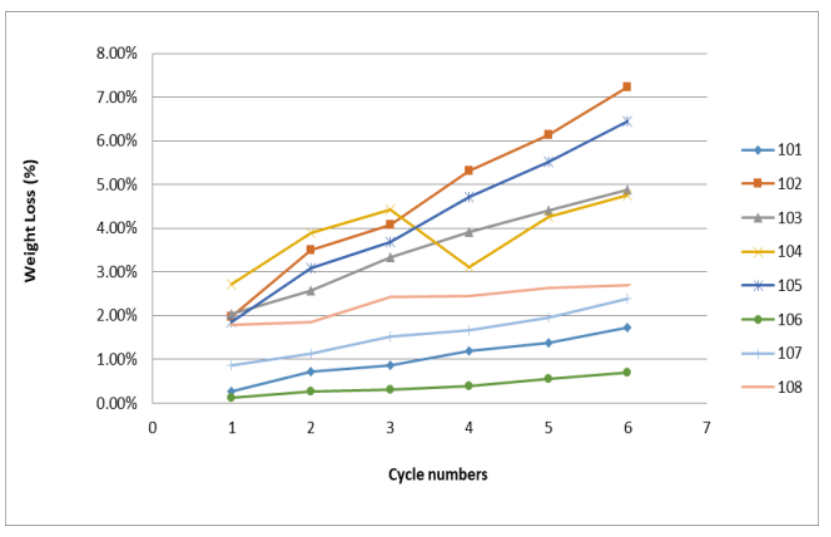

Figure 3. Abrasion strength of materials (cycle numbers x 5000)

The best result was obtained from aluminized aramid sample. It may be due to metalic coating on the fabric gave it protection layer against abrasion. Meta-aramid fabric and cotton denim fabric samples are following aluminized aramid. Modacrylic-viscose-FR cotton blended fabric was the worst sample in abrasion test. Thickness may be the reason hence this fabric is the thinnest fabric sample $[13,16]$.

\section{3 pH Value and Fat Content of the Leather}

The results of $\mathrm{pH}$ value measurements and fat content of leather is seen in Table 3.

Table 3. $\mathrm{pH}$ values of the samples and fat content of the leather

\begin{tabular}{lr}
\hline Fabrics & pH values \\
\hline 101 - meta-aramid & 6.66 \\
102 - Modacrylic-Viscose-FR cotton & 6.65 \\
103 - Cotton 1- FR1 & 7.26 \\
104 - Leather Mean Fat Content: $0.862 \%$ & 3.75 \\
105 - Cotton 2- FR 2 & 8.72 \\
106 - Aluminized aramid & 6.45 \\
107 - Cotton 3 - Denim & 7.65 \\
108 - FRViscose-Wool-Polyamide & 7.86 \\
\hline
\end{tabular}

Because these workwear fabrics are in direct contact with skin, their $\mathrm{pH}$ value must be harmless to skin of the wearer. For innocouousness, $\mathrm{pH}$ should be close to neutral $\mathrm{pH}(\mathrm{pH}$ 7). Except leather, all test samples seem to have compatible 
pH degree with human skin. Fat content of leather materials should be below 15\% according to TS EN ISO 11612. Therefore, the leather sample of this study is suitable for this criteria.

\subsection{Limited Flame Spread}

The criteria when applying this test are not quantitative. Requirements of TS EN ISO 11612 are no specimen shall permit any part of the lowest boundary of any flame to reach the upper or either vertical edge; no specimen shall give flaming or molten debris; no specimen shall give hole formation of $5 \mathrm{~mm}$ or greater in any direction, except for an interlining that is used for specific protection other than heat and flame protection; afterglow time shall be $\leq 2$ s and afterflame time shall be $\leq 2 \mathrm{~s}$. If all criteria are fulfilled, this means that the sample passes the test. The results of this test is given in Table 4.

Table 4. Results of limited flame spread test

\begin{tabular}{lcc}
\hline \multicolumn{1}{c}{ Fabric type } & $\begin{array}{c}\text { Fabric } \\
\text { Thickness } \\
(\text { mm })\end{array}$ & $\begin{array}{c}\text { Vertical Flame } \\
\text { Spread Test- } \\
\text { (Pass / Fail })\end{array}$ \\
\hline $\begin{array}{l}\text { Meta-aramid } \\
\text { Modacrylic-Viscose-FR }\end{array}$ & 0,642 & Pass \\
cotton & 0,474 & Fail \\
Cotton 1- FR1 & 1,110 & \\
Leather & 1,042 & Pass \\
Cotton 2- FR 2 & 0,708 & Pass \\
$\begin{array}{l}\text { Aluminized aramid } \\
\text { Cotton Denim 3 }\end{array}$ & 0,736 & Pass \\
$\begin{array}{l}\text { FRViscose-Wool- } \\
\text { Polyamide }\end{array}$ & 0,780 & Fail \\
\hline
\end{tabular}

In this test, inherently flame retardant meta-aramid fabric, flame retardant treated cotton fabrics and leather passed the criteria as expected. The other fabrics showed worse results because their 'afterflame time' exceeded limits, even aluminized fabric. Aluminized fabrics are produced mainly for heat reflectance. Besides, because its high thermal conductivity causes other types of heat transfer easily to fabrics lowering protection properties. Additionally, aluminium can melt under the flame condition, due to flame temperature of propane is higher than its melting burning point as approximately $660^{\circ} \mathrm{C}$ (in our device we measured flame temperature approximately $720^{\circ} \mathrm{C}$ ) [17-19].

\subsection{Molten Aluminium Protection Test}

Starting amount of molten aluminium was $50 \mathrm{~g}$. Evaluation criteria for the test is any damage in the size of $5 \mathrm{~mm}$ in width on PVC skin simulator. The results are given in Table 5.

As seen from the table, protection degrees of the samples are in two extreme group. One half of the fabrics are maximum protective against molten aluminium but the other half is absolutely inadequate to use in this field even they have flame retardant properties. We can conclude that flame retardant property does not refer to molten aluminium protective property, similar to literature [5]. In Figure 4, pictures of results of protective fabrics are shown. Aluminized fabric is also protective and image of samples tested with different molten aluminium weights are given in Figure 5. Result from fabric sample 101-meta-aramid was given in Figure 1.(b).

Table 5. Molten aluminium protection test results

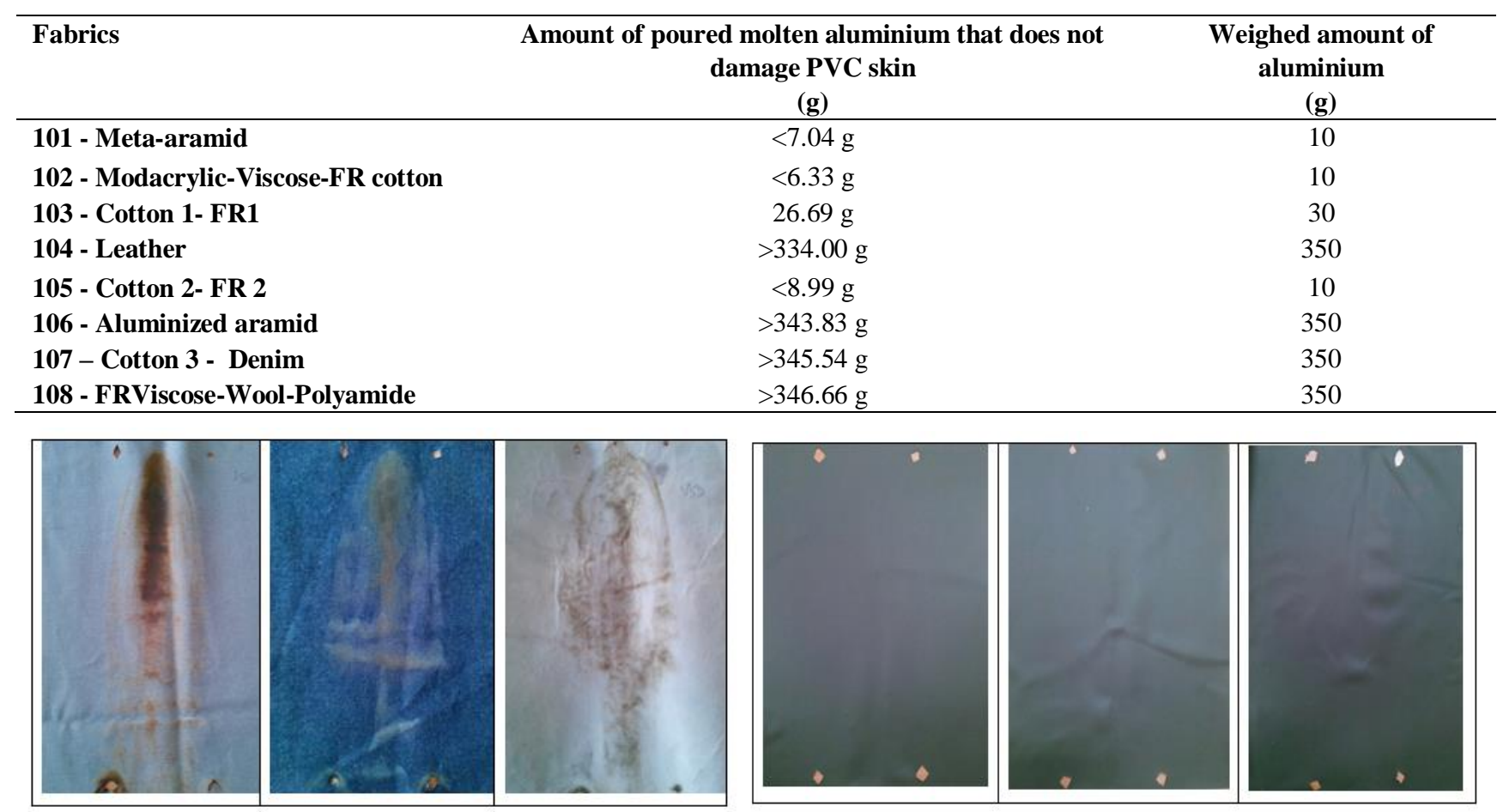

Figure 4. 350g - molten aluminium tested samples and related PVC skin simulant (from left to right: LenzingFR-Wool-Polyamide, Cotton 3-Denim, leather) 

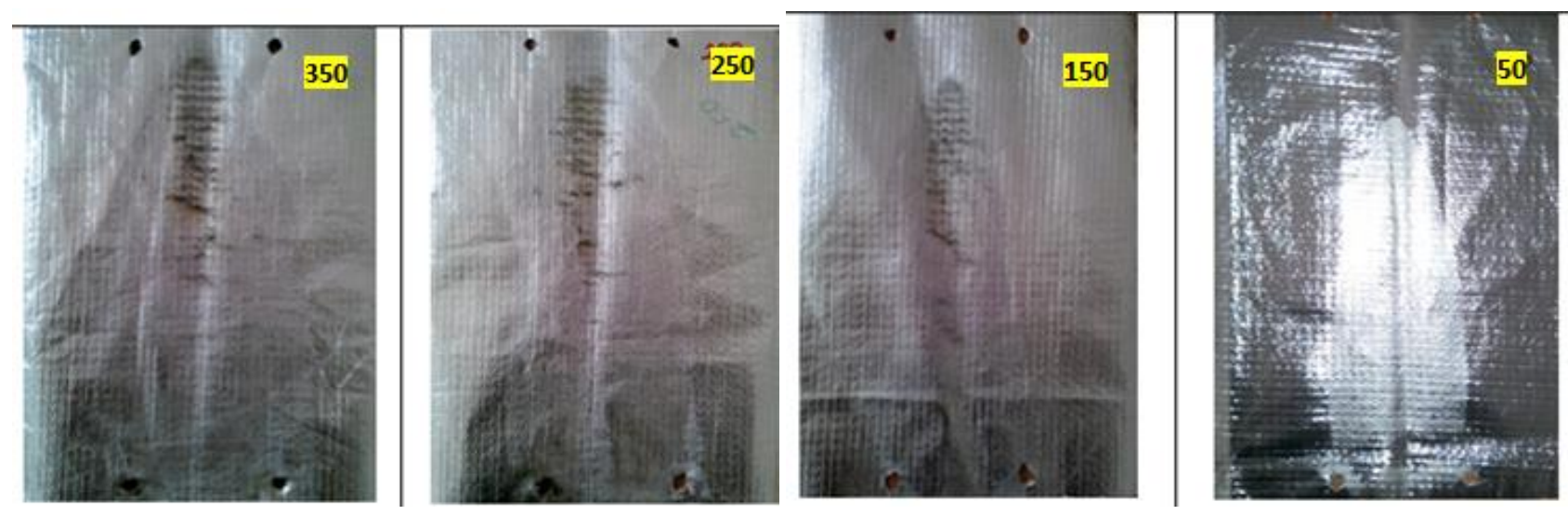

Figure 5. Aluminized aramid fabric tested with different amounts of molten aluminium

As seen from the Figure 1(a), meta-aramid fabrics showed a sticky surface for aluminium metal, therefore, damage to PVC skin was severe. The reason is softening of metaaramid fibers when a molten metal poured on. Figure 4 shows the views of $350 \mathrm{~g}$ weigthed aluminium poured materials (leather, denim and LenzingFR-wool-polyamide) and PVC skins. As seen in the picture, none of the fabrics shrinked and was damaged, PVC film was not damaged, too. Figure 5 shows the change on the surface of aluminized aramid fabric. Altough surface was changed by increasing amount of molten aluminium, PVC skin was not damaged.

\subsection{Water, Watervapor and Air Permeability Tests}

In addition to protection, permeability properties must be taken into account because using the protective clothing at work require comfort and ability to work with these clothes (Table 6).

Air and water vapor permeability properties are related to comfort feeling of a textile structure. Feeling comfortable is important to be able to do work properly in any work field. From the table, air permeability values of leather and aluminized fabric seem to feel workers uncomfortable because they are not breathable. Aluminized fabric has a water vapor permeability value lowest among others, however, leather has some watervapor permeability to permit watervapor to pass through. Except from aluminized aramid, none of the fabrics have water resistancy. In fact foundry work does not need water resistancy, if the work is realized in outdoor condition.

\section{CONCLUSION}

All these fabric samples were available for molten metal industry in Turkey, even from expert suppliers or from conventional workwear fabric sellers. Wide range of physical and performance properties were obtained from the tested eight different materials. Besides having good protective performances, some samples showed poor comfort related properties. Except from leather, metaaramid and two FR cotton fabrics, other fabrics were failed from flame spread test because same specimens continued burning. Contrary to results of the flame spread test, leather, aluminized aramid, FR viscose-wool-polyamide and cotton denim materials show the highest values in molten metal protection test. Regarding flame spread test and molten metal protection, only leather sample showed good results for both tests. However, leather has some water vapor permeability but has no air permeability. This means protection good but comfort of the wearer cannot be obtained. For this reason, as a result, novel protective fabrics may be investigated to be used in our country for molten metal protection. Besides, as an alternative, in the production of protective clothing for foundry workers, a clothing design approach combining different materials in one clothing in order to obtain protection, comfort, and affordability at the same time should be regarded for engineered manufacturing.

\section{Acknowledgement}

This work was supported by Dokuz Eylul University under Grant number 2013.KB.FEN.032. The authors want to thank to Ege University Leather Engineering Department for leather experiments and to Dokuz Eylul University Metallurgical and Materials Engineering for melting processes of aluminium.

This study was presented in $7^{\text {th }}$ European Conference on Protective Clothing. 
Table 6. Air and water vapor permeability and water resistance results

\begin{tabular}{lrrr}
\hline Fabrics & $\begin{array}{c}\text { Air permeability } \\
\left(\mathbf{1} / \mathbf{m}^{\mathbf{2}} \mathbf{s}\right)\end{array}$ & $\begin{array}{c}\text { Water vapor permeability index } \\
(\mathbf{\%})\end{array}$ & $\begin{array}{c}\text { Water resistance } \\
(\mathbf{c m}-\text { water column) }\end{array}$ \\
\hline $\mathbf{1 0 1}$ - Meta-aramid & 80.56 & 103.29 & 20.7 \\
$\mathbf{1 0 2}$ - Modacrylic-Viscose-FR cotton & 81.80 & 95.07 & 23.4 \\
$\mathbf{1 0 3}$ - Cotton 1- FR1 & 89.96 & 94.37 & 23.7 \\
$\mathbf{1 0 4}$ - Leather & 0.00 & 79.41 & 53.1 \\
$\mathbf{1 0 5}$ - Cotton 2- FR 2 & 160.20 & 129.52 & $\mathrm{~N} / \mathrm{A}$ \\
$\mathbf{1 0 6}$ - Aluminized aramid & 4.29 & 7.62 & 310.0 \\
$\mathbf{1 0 7}$ - Cotton 3 - Denim & 52.92 & 110.80 & 13.8 \\
$\mathbf{1 0 8}$ - FRViscose-Wool-Polyamide & 77.34 & 94.76 & $\mathrm{~N} / \mathrm{A}$ \\
\hline
\end{tabular}

\section{REFERENCES}

1. Tudoksad (Turkish Foundry Association), 2020, April 20, We add value to metals, retrieved from https://www.tudoksad.org.tr/upload/ files/Dokum_Sanayi_Bilgi_Foyu.pdf

2. Mäkinen, H. 2013. Flame Resistant Textiles for Molten Metal Hazards, In F.S. Kilinc (Ed.), Handbook of Fire Resistant Textiles, Cambridge: Woodhead Publishing Limited, pp.581-602.

3. Barker, R., Yener, M. 1981. Evaluating the Resistance of Some Protective Fabrics to Molten Iron, Textile Research Journal 1981; 51; 533

4. Benisek, L., Edmondson, G.K., Philips, W.A. 1979. Protective Clothing-Evaluation of Wool and Other Fabrics, Textile Research Journal 1979; 49; 212

5. Benisek, L., Edmondson, G.K., 1981. Protective Clothing Fabrics: Part I. Against Molten Metal Hazards1 Textile Research Journal $1981 ; 51 ; 182$

6. Proctor, T.D. and Thompson, H. 1992. Effect of Fabric Finish On the Adhesion of Molten Metal to Wool, Performance of Protective Clothing: Fourth Volume, ASTM STP 1133, James P. McBriarty and Norman W.Henry, Eds., American Society for Testing and Materials, Philadelphia

7. Benisek, L., Edmondson, G.K., 1984. Effect of Chrome Dyeing on Protection of Wool Against Molten Aluminium, Textile Research Journal 1984; 54; 214

8. Coughlan, J.E. 1992. Protective Clothing Development at New Zealand Aluminum Smelters Ltd., Performance of Frotective Clothing; Fourth Volume, ASTM STP 1135, J. P. McBriarty and N. W. Henry, Eds., American Society for Testing and Materials, Philadelphaia, p.252

9. Magnússon, V., Gunnarsson, G. \& Jónsson, H. 2001. Safety Clothing for the Aluminium Industry, 1st International Conference and Workshop on Anode Rodding Plants for Primary Aluminium, Reykjavik, Iceland

10. Mäkinen, H., Laiho, H., Pajunen, P., 1997. 'Evaluation of the Protective Performance of Fabrics and Fabric Combinations against
Molten Iron,' Performance of Protective Clothing: Sixth Volume, ASTM STP 1273, Jeffrey O. Stull and Arthur D. Schwope, Eds., American Society for Testing and Materials.

11. Lee, M, 2009. Recent Developments In Australian Aluminium Casthouse Personal Protective Clothing, Materials Science Forum, Vol.630, pp.19-25.

12. Gabara, V. 1994. High performance fibers 1: Aramid fibers, H. Brody, (Ed.), Synthetic fiber metarialism, New York: Longman publishing group. pp.239-260

13. Hearle, J. W. S. ve Morton, W E. (2008), Physical properties of textile fibres (4th Ed.). Cambridge: Woodhead Publishing Limited.

14. Fan, J. (2009). Durability of fabric and garment. J. Fan. ve L. Hunter, (Ed.), Engineering Apparel Fabrics and Garments. Boca Raton: Woodhead Publishing Limited. pp.161-195.

15. Bunsell, A.R. (Ed.) 2009. Handbook of tensile properties of textile and technical fibres. United Kingdom: Woodhead Publishing Limited.

16. Horrocks, A. R. 2014. High performance textile for heat and fire protection. C. Lawrence, (Ed.), High Performance Textile For Heat and Fire Protection. Cambridge: Woodhead Publishing Limited. pp.144-190.

17. Udayraj, Talukdar, P., Das, A., Alagirusamy, R. 2016. Heat and mass transfer through thermal protective clothing - A Review, International Journal of Thermal Sciences, 2016, 106, 32.

18. Hao, L., Yu, W. 2011. Comparison of thermal protective performance of aluminized fabrics of basalt fiber and glass fiber, Fire and Materials, 2011, 35, 553.

19. Jin, L., Park, P. K., Hong, K.A., Yoon, K.J. 2015. Effect of Aluminized Fabrics on Radiant Protective Performance of Fire Proximity Suit Materials, Annals of Occupational Hygiene, 2015, 59, 243. 